\title{
Modern era Knowledge Spillovers in the Solar energy sector
}

\author{
JONAS GRAFSTRÖM* \\ The Ratio Institute and Luleå University of Technology \\ SE-113 59 Stockholm \\ Sweden \\ E-mail: jonas.grafstrom@ratio.se
}

\begin{abstract}
The purpose of this paper is to provide an updated analysis of international knowledge spillovers in the solar energy sector. Specifically, the paper investigates how the accumulation of solar energy patents and public R\&D spending affected the output of domestic granted solar energy patents. The econometric analysis relies on a data set consisting of most of the OECD countries plus China and analyzes two time periods; from 1990 to 2014 and the years 2000 to 2014. To analyze the data material, a Poisson fixed-effects estimator based on the Hausman, Hall and Griliches (1984) method was used. The empirical findings suggest that the domestic accumulation of patents and R\&D is important for the potential development of new ones. Indeed, early investment in specific technology can be an indicator of future leadership in that field. It also seems to be the case that long run investment works better for a country that wants to be a part of the development of a particular technology.
\end{abstract}

Keywords: Solar PV, R\&D, Spillovers, patents.

JEL classification: E61, O32, Q2, Q58.

\footnotetext{
* Luleå University of Technology Economics Unit. SE-971 87 Luleå, Sweden: jonas.grafstrom@ltu.se and the Ratio institute, Stockholm. Declarations of interest: none. Responsibility for any remaining errors resides solely with the author.
} 


\section{Introduction}

There is an increasing interest in assessing the knowledge spillover effects of renewable energy R\&D policies - policies that play an important role in stimulating innovation in the renewable energy sector (De Vries and Withagen, 2005; Johnstone et al., 2012; Johnstone, Hascic, and Popp, 2010; and Tang, 2018). Public R\&D spending in renewable energy technologies is expected to enhance, and hence lift, other technologies through knowledge spillovers (see e.g., Cohen and Levinthal, 1989; Hussler, 2004; Antonelli, 2008; Costantini and Crespi, 2008a; Antonelli and Quatraro, 2010).

However, the renewable energy spillover literature has concentrated on within-industryspillovers in the rather early stages of the development of renewable energy, mostly covering the time period 1990-2014 (see, e.g., Klaassen et al., 2005; Mancusi, 2008; Aldieri and Cincera, 2009; Braun, 2011; Corradini et al., 2014; Lehmann, 2013; Grafström 2018a; Grafström and Lindman 2017). Most research has been focused on wind power to the neglect of solar power. The recent two decades have seen an unprecedented growth in several renewable energy sources, yet the time period is under researched.

The purpose of this paper is to provide an updated analysis of international knowledge spillovers in the solar energy sector. The paper investigates how the accumulation of solar energy patents and public R\&D spending affected the output of domestic granted solar energy patents. The paper draws methodologically from Grafström, 2018a; 2018b who has made similar studies in the field of wind power, but adds another econometric approach. Solar power is also a fast-growing renewable energy production method with its own benefits and downsides. The results obtained from this paper are therefore important for policymakers concerned with solar power since we cannot assume that all technologies are similar in their ability to produce knowledge spillovers.

The paper therefore adds to the existing literature in the sense that it: (a) expands the existing knowledge spillover literature concerning international spillovers in the solar industry to the modern era; (b) applies another economic approach to knowledge spillovers; and (c) our understanding of international knowledge spillovers in another energy field is enhanced. Two research questions are considered:

- Does the accumulation of solar energy patents in a country affect the output of solar power patents in neighboring countries? 
- Does the public R\&D spending affect the output of domestic granted solar energy patents?

The econometric analysis relies on a data set consisting of most of the OECD countries plus China $^{1}$ and analyzes two time periods; from 1990 to 2014 and the years 2000 to $2014 .^{2}$ The usage of two time periods is motivated by the fact that there was a significant increase of solar patents at the beginning of the 2000s. ${ }^{3}$ To analyze the data material, a Poisson fixed-effects estimator based on the Hausman, Hall and Griliches (1984) method was used since the model allows for count data estimations. ${ }^{4}$ To empirically investigate the two posed questions a socalled knowledge production function is estimated; the rate of new knowledge creation is assumed to depend on, for instance, the environmental policy stringency, ${ }^{5}$ public $\mathrm{R} \& \mathrm{D}$ spending and the patents-based stock of knowledge available to these researchers (e.g., Ibenholt, 2002; Klaassen et al., 2005; Krammer, 2009; Söderholm and Klaassen, 2007; Joutz and Abdih, 2005).

Studying knowledge spillovers is highly relevant. In the presence of international knowledge spillovers, countries can choose a free-riding approach where a sub-optimal amount of R\&D expenditures are allocated towards renewable energy (Garrone and Grilli, 2010). Hence, it is important to understand and handle incentives for free-riding (e.g., Mansfield et al., 1977; Jaffe et al., 2005; Popp, 2005; Fischer, 2008) because countries might try to absorb spillovers and make use of the technologies invented abroad. For the development towards an energy sector free from carbon emissions, knowledge spillovers are mostly a positive thing (free-riding could lead to a faster implementation of renewable energy at a lower cost). However, a country's ability to make use of new technology and to respond efficiently to changes in the external constraints will depend on its technological capabilities and on its so-called absorptive capacity (Antonelli, 2008; Antonelli and Quatraro, 2010; Costantini and Crespi, 2008a, 2008b; Dosi et al., 1988; Fagerberg et al., 2005; Rennings, 2000). ${ }^{6}$

\footnotetext{
${ }^{1}$ The Countries are Australia, Austria, Belgium, Canada, Chile, China (People's Republic of), Czech Republic, Denmark, Estonia, Finland, France, Germany, Greece, Hungary, Iceland, Ireland, Israel, Italy, Japan, Korea, Luxembourg, Mexico, Netherlands, New Zealand, Norway, Poland, Portugal, Slovak Republic, Slovenia, Spain, Sweden, Switzerland, Turkey, United Kingdom, United States. The broad choice of countries on several continents is motivated by the fact that during the selected time period the solar industry had grown and become multinational, consequently companies from all parts of the world were selling components to each other.

${ }^{2}$ Priority date is used, additional robustness test with other time periods were also tested.

${ }^{3}$ The early time period saw a slow growth of patents whilst the later period saw a fast increase.

${ }^{4}$ A negative binomial model could also have been used, a discussion about the decision to use the somewhat criticized Poisson fixed-effects estimator is presented in the section concerning "Econometric issues".

${ }^{5}$ Most of the renewable technologies have not yet reach grid parity (in all geographical areas), public policies have been implemented in order to foster their deployment.

${ }^{6}$ In the context of this paper absorptive capacity refers to a country's ability to absorb knowledge developed abroad. The ability of international technology flows to affect a country's technological level crucially depends on the destination country's ability to comprehend and make use of external knowledge (Verspagen, 1991; Mancusi, 2008).
} 
From a general policy perspective, the necessity of developing renewable energy, and developing it sooner rather than later, should not be underestimated. Human economic activity, which still is highly dependent on fossil fuels, is increasing the atmospheric concentrations of $\mathrm{CO}_{2}$, surpassing 400 parts per million ( $\mathrm{ppm}$ ) compared to an historical value of around $250 \mathrm{ppm}$ (EPA, 2016). The increased concentrations of greenhouse gases (GHG) may cause a transformation of our climate towards a critical mix of dangers (e.g., changed weather patterns with increased variability, rising sea levels and droughts etc.) (e.g., Dietz and Maddison, 2009; Suganthi and Samuel, 2012). To mitigate the concentration of $\mathrm{CO}_{2}$ diffusion of new carbonfree or low carbon technologies is essential - knowledge spillovers are one way to increase the speed of that diffusion (Stern, 2007).

The remainder of the paper is organized as follows. Section 2 introduces three important concepts regarding knowledge spillovers. Section 3 presents the model specification and discusses some important econometric issues, whilst section 4 provides a description of the data definitions and sources. Section 5 reports on the results from the different empirical specifications, whilst section 6 synthesizes the empirical findings and discusses the results. Section 7 contains the conclusions and policy implications.

\section{Innovation - The role of Knowledge Spillovers and crowding out}

In this section, three conceptual topics that are important for the paper will be presented and discussed. Specifically, these three concepts are: (a) Knowledge Spillovers; (b) Knowledge Spillovers in the renewable energy sector with an emphasis on the solar sector.; and (c) Knowledge Spillovers and Free-riding, here commented on in more detail with reference to relevant research done in the renewable energy sector.

\subsection{Knowledge Spillovers}

In general, theoretical terms, if a country (firm) lack capabilities to assimilate new knowledge, spill-overs will occur at a sub-optimal level (Verspagen, 1991). In a letter written by Isaac Newton in the year 1676 the phrase "If I have seen further it is by standing on ye shoulders of Giants" was coined. The phrase can be interpreted as: progress in science builds on previous findings. Following Newton's intuition; a key characteristic of technological change is that innovation in a country builds upon prior existing knowledge and the ability to absorb new knowledge (Dosi, 1982; Aldieri and Cincera, 2009; Mancusi, 2008). A significant part of the previous literature on technological change has emphasized the significance of the cumulative 
character of knowledge for the expansion of further technological improvements (Griliches 1979, 1992; Antonelli 2008; Costantini and Crespi 2008a, 2008b).

There are according to Griliches $(1979,1992)$ two major distinguishable types of spillover. Pure knowledge spillover and Rent Spillovers. Pure spillovers are not incorporated into tradable goods, rather, the relevant knowledge is instead transferred from one firm to another without the recipient of the knowledge directly paying the producer of the knowledge. Rent spillovers arise when the improvement in physical productivity derived from technological innovation within a product is not followed by a price change of the same magnitude.

Pure- and Rent knowledge spillovers move from one agent to another in two stylized ways (Glaeser et al., 1992). The first builds on a Jacob-type externality frame; knowledge produced by other actors (e.g., a country) may be a useful input for the domestic knowledge production function of all other actors (irrespective of previous experience). In the other setting, i.e., a Marshall-type externality setting, knowledge only flows between various homogeneous actors (Corradini et al., 2014).

Furthermore, the domestic absorptive capacity is important when it comes to understanding the capacity a country must transform imported technology into productivity gains in its production apparatus (Engelbrecht, 1997; and Nelson and Phelps, 1966). Hence, the ability to receive technological spillovers or use advancements made abroad is a function of the country's experience in $R \& D$, if there is no absorptive capacity then the spillover flow might not exist (Cohen and Levinthal, 1989).

\subsection{Knowledge Spillovers in the renewable energy sector with an emphasis of the solar} sector.

In the renewable energy sector, the empirical evidence, on the country level ${ }^{7}$, of the existence of international knowledge spillovers is somewhat limited. Peters et al. (2012) found evidence of public policy-related spillovers in the solar PV industry. Braun et al. (2010) studied solar and wind power finding no knowledge spillover effects between 21 OECD countries between 1978 and 2004. Grafström and Lindman (2017) and Grafström (2018a) found evidence of knowledge spillovers in the wind sector and Tang (2018) found evidence of knowledge spillovers on wind farm operation at the US state level. Johnstone et al. (2012) investigated the determinants of

\footnotetext{
${ }^{7}$ There are other studies (which were more focused on the firm level) that have investigated knowledge spillovers, and the determinants of renewable energy patents. Aldieri and Cincera (2009) used the knowledge-stock approach to study spillovers between large international R\&D companies' productivity growth. Corradini et al. (2015) found that the positive correlation between environmental and innovation performances might be reinforced by different spillover mechanisms. Furthermore, the knowledge stock of previously filed patents is included in many patent count models to account for a country's absorptive capacity (Peters et al., 2012; Cohen and Levinthal, 1990).
} 
environmentally related patents (e.g., for wind and solar power), and found that both general innovative capacity and environmental policy stringency have played positive roles in environment related innovation.

In addition, in an effort to measure spillovers, Dechezleprêtre et al. (2013) compared the intensity of patent citations in clean energy with their less-clean counterparts. Finding that, clean energy patents are cited more frequently than patents based on less-clean technologies. Furthermore, Poirier et al. (2015) estimated a knowledge production function, analyzed the effect of international co-authorship of scientific publications on patenting in wind energy technologies within the OECD and the non-OECD countries. Their results suggest that knowledge spillovers exist between these country groups. Corradini et al. (2014) studied how firms and sectors in 15 European Union (EU) countries and 23 manufacturing sectors had been affected by environmental protection decisions in other firms, sectors, or countries.

\subsection{Knowledge Spillovers and Free-riding}

Knowledge spillovers can bring about free-riding. Mansfield et al. (1977) found that the public social benefits of investments in innovation were larger than the firms' private benefits. The gap between the private and social benefits of R\&D can lead to underinvestment in R\&D (Jaffe et al., 1995; Popp, 2005; Fischer; 2008).

The free riding incentive problem may also arise because of technological development efforts based on learning in the production and use of technology, i.e., learning-by-using and learningby-doing (e.g., Arrow, 1962). For example, demand-pull policies (e.g., feed-in tariff schemes) have been found to create significant cross-country innovation spillovers, which in turn could serve as disincentives for national policy makers to engage in domestic market creation and thus drive them to adopt a free-riding approach instead (e.g., Peters et al., 2012). However, in a recent paper Baudry and Bonnet (2018) found that a free-riding strategy is not a good option for a country that targets diffusion of wind power.

In the presence of international knowledge spillovers, countries can choose a free-riding approach where a sub-optimal amount of $R \& D$ expenditures are spent. Instead, they try to absorb spillovers and make use of the technologies invented abroad. For the development towards an energy sector free from carbon emissions, knowledge spillovers can be either positive or negative (free-riding could lead to a faster implementation of renewable energy at a lower cost). However, a country's ability to make use of new technology will depend on its technological capabilities and on its so-called absorptive capacity. Absorptive capacity here concerns countries' abilities to absorb knowledge developed abroad; the effect of international 
technology flows crucially depends on the destination country's ability to comprehend and make use of external knowledge (Mancusi, 2008). For a country to respond efficiently to changes in the external constraints, it needs to be equipped with adequate scientific and technological knowledge, i.e., a country needs to build absorptive capacity (Antonelli 2008; Costantini and Crespi 2008a, 2008b; Dosi et al., 1988; Rennings, 2000; Fagerberg et al., 2005; Antonelli and Quatraro, 2010).

For the above reasons it is highly relevant to identify and study knowledge spillovers in the renewable energy sector. The presence (or absence) of cross-border technological spillovers is likely to influence government policies on, for instance, public R\&D support and the implementation of technology deployment schemes. If knowledge does not spill over, it is more reasonable for a national government to invest in building up a green industry domestically without having to free-ride on other countries' efforts. If, however, the knowledge generated in one country is found to spill over freely to a neighbor then it could be more effective and efficient for cross-governmental entities, such as the EU, to devise and implement R\&D policies. If proper policy measures are not implemented there is a risk that the countries will diverge in their technological capabilities, and this will hamper their ability to make use of new knowledge as well as give rise to a non-optimal global response to the climate change challenge (Grafström 2018b).

\section{Model Specifications and Econometric Issues}

\subsection{Model Specification}

The empirical approach for assessing spillovers in the solar energy sector stems from various previous studies (e.g., Klaassen et al., 2005; Antonelli et al. 2011; Boschma and Iammarino 2009; Corradini et al., 2014). Our empirical work is related to the literature which uses patent counts to measure inventions and innovation in renewable energy technologies (Popp, 2002; Dekker et al, 2012; Johnstone and Haščič, 2010; Braun et al., 2011; Grafström and Lindman 2017; and Grafström, 2018a). ${ }^{8}$ The baseline for the empirical estimations is presented in

\footnotetext{
${ }^{8}$ Using patent data covering eleven different energy technologies, Popp (2002) finds evidence for significant intra-technology knowledge spillovers. Johnstone and Haščič (2010) also find inter-technology spillovers, showing that previous knowledge accumulated in storage technologies positively affect innovation in other clean technologies. Most studies that have concerned environmentally related patents have tended to focuse on how public policies affect innovative activity. Johnstone et al. (2010) found that different policies are better or less well-suited regarding inducing innovations. De Vries and Withagen (2005) use environmentally related patents in Europe as environmental innovation indicators. They measure policy stringency, with an underlying idea about a connection between high emission levels, which trigger strict environmental policy, thus creating stronger incentives for innovation. Grafström (2018b) found divergence of energy invention capabilities across the 13 EU countries.
} 
equation (1), a production function of patents commonly encountered in the literature is presented:

$P C_{n t}=\beta_{0}+\beta_{1} E R_{n t-3}+\beta_{2} R \& D_{n t-3}+\beta_{3} \mathrm{~K}_{n t}+\alpha_{n}+T_{n}+\varepsilon_{n t}$

where the dependent variable, $P C_{n}$, is a count of solar power patents applications in country $n$ $(n=1, \ldots, N)$ for a given year $t(t=1, \ldots, T)$ i.e., the year the granted patent had its priority year. Public solar power R\&D expenditures $\left(R \& D_{n t}\right)$ and an Environmental Policy Stringency Index $\left(E R_{n t}\right)$ are control variables for the general level of research output capacity in the country. These control variables are lagged three years (more variables are incorporated in the models, they are described in more detail in section 4.2 The Independent variables). For example, public $\mathrm{R} \& \mathrm{D}$ expenditures taking place in period $t$ may lead to a patent application and, eventually, to a patent being granted no earlier than in period $t+x(x=3)$ (Nicolli et al., 2012). $K_{n t}$ is a domestic solar power patent-based knowledge stock in country $n$ in period $t$. In the based model (equation 1), each country's separate knowledge stock consists of an accumulation of previously assembled solar power patents in that country, here denoted as the national knowledge stock.

Moreover, the patent-based stocks are constructed with a three-year lag and a 15 percent depreciation rate (see further section 4). Country-specific fixed effects, $\alpha_{n}$, are introduced to capture any unobservable country-specific heterogeneity. Time dummies, $T_{n}$, are also included. The econometric analysis includes time dummies, and therefore a concern is remedied - that the coefficients on the variables of interest capture shocks correlated with both the level of R\&D policies and the knowledge stocks, and innovation activity. This could include any macroeconomic shocks and one can contemplate plenty of such unobserved variables that may cause the coefficients to be strongly biased. The error term captures all the residual variation, $\varepsilon_{n t}$.

Model I presented in equation (1) is the baseline upon which eight additional model specifications (II-VIII) will be built. The time period 1990-2014 is tested for the specifications. The different specifications (Models I-VIII) of the patent production model are presented in Table 1. 
Table 1: Patent production model specifications

\begin{tabular}{|c|c|c|}
\hline Model & Estimated model specification & Description \\
\hline I & $P C_{n t}=\beta_{0}+\beta_{1} E R_{n t-3}+\beta_{2} R \& D_{n t-3}+\beta_{3} \mathrm{~K}_{n t}+\alpha_{n}+T_{n}+\varepsilon_{n t}$ & $\begin{array}{l}\text { Base model with national } \\
\text { knowledge stock and R\&D } \\
\text { flow 1990-2014. }\end{array}$ \\
\hline II & $P C_{n t}=\beta_{0}+\beta_{1} E R_{n t-3}+\beta_{2} R \& D_{n t-3}+\beta_{3} \mathrm{IK}_{n t}+\alpha_{n}+T_{n}+\varepsilon_{n t}$ & $\begin{array}{l}\text { International knowledge } \\
\text { stock and R\&D flow 1990- } \\
2014 \text {. }\end{array}$ \\
\hline III & $P C_{n t}=\beta_{0}+\beta_{1} E R_{n t-3}+\beta_{2} R \& D S_{n t-3}+\beta_{3} \mathrm{~K}_{n t}+\alpha_{n}+T_{n}+\varepsilon_{n t}$ & $\begin{array}{l}\text { Base model with national } \\
\text { knowledge stock and R\&D } \\
\text { Stock 1990-2014. }\end{array}$ \\
\hline IV & $P C_{n t}=\beta_{0}+\beta_{1} E R_{n t-3}+\beta_{2} R \& D_{n t-3}+\beta_{3} \mathrm{IK}_{n t}+\alpha_{n}+T_{n}+\varepsilon_{n t}$ & $\begin{array}{l}\text { International knowledge } \\
\text { stock and R\&D flow 1990- } \\
2014 \text {. }\end{array}$ \\
\hline $\mathrm{V}$ & $P C_{n t}=\beta_{0}+\beta_{1} E R_{n t-3}+\beta_{2} R \& D S_{n t-3}+\beta_{3} \mathrm{~K}_{n t}+\alpha_{n}+T_{n}+\varepsilon_{n t}$ & $\begin{array}{l}\text { Base model with national } \\
\text { knowledge stock and R\&D- } \\
\text { Stock 2000-2014. }\end{array}$ \\
\hline VI & $P C_{n t}=\beta_{0}+\beta_{1} E R_{n t-3}+\beta_{2} R \& D S_{n t-3}+\beta_{3} \mathrm{IK}_{n t}+\alpha_{n}+T_{n}+\varepsilon_{n t}$ & $\begin{array}{l}\text { International knowledge } \\
\text { stock and R\&D-Stock } \\
\text { 2000-2014. }\end{array}$ \\
\hline VII & $P C_{n t}=\beta_{0}+\beta_{1} E R_{n t-3}+\beta_{2} R \& D S_{n t-3}+\beta_{3} \mathrm{~K}_{n t}+\alpha_{n}+T_{n}+\varepsilon_{n t}$ & $\begin{array}{l}\text { Base model with national } \\
\text { knowledge stock and R\&D- } \\
\text { Stock 2000-2014. }\end{array}$ \\
\hline VIII & $P C_{n t}=\beta_{0}+\beta_{1} E R_{n t-3}+\beta_{2} R \& D S_{n t-3}+\beta_{3} \mathrm{IK}_{n t}+\alpha_{n}+T_{n}+\varepsilon_{n t}$ & $\begin{array}{l}\text { International knowledge } \\
\text { stock and R\&D-Stock } \\
\text { 2000-2014. }\end{array}$ \\
\hline
\end{tabular}

Models I-IV analyze the development of knowledge spillovers originating in the solar power field, including the role of international solar power knowledge spillovers between 1990 and 2014. A positive statistically significant result would indicate knowledge spillovers whilst a negative statistically significant sign could indicate a crowding out effect. Models V-VIII mirror Models I-IV but cover the period 2000-2014.

Specifically, Model II includes an international stock. Model III tests the same variables as Model I but with a R\&D stock instead. Model IV mirrors Model II but with a R\&D stock instead. Models V-VIII address the same set up as Models I-IV but consider a later time period, 2000-2014.

\subsection{Conceptual and Econometric Issues}


There are econometric and conceptual criticisms against the use of patent data as a measure of invention output (see e.g. Johnstone, Managi, Rodríguez, Haščič, Fujii, and Souchier, 2017 and Grafström, 2018a). ${ }^{9}$ However, patent data has been commonly used econometric studies as approximations of the impact of technological change and invention (e.g. Budd and Hobbis, 1989a, 1989b; Fagerberg, 1988; Jungmittag, 2004; Jungmittag and Welfens, 2002; Jungmittag et al., 1999). The main concern is that not all new inventions are patented, and patents differ greatly in their economic impacts (Pakes and Griliches, 1980, 378). Moreover, the economic value of patents varies, and some become economically worthless within a relatively short period (Pakes, 1985; Schankerman and Pakes, 1987). The top 10\% of patents have been estimated to capture most of the total monetary returns, between $48 \%$ and $93 \%$ (Scherer and Harhoff, 2000).

Furthermore, it has been argued that small firms find the application process difficult; as a result, they may not bother applying (Adams 2005). Another strategy is that firms will employ various types of secrecy to shroud their production methods (Cohen, Nelson, and Walsh 2000; Trajtenberg 2001). But, as Griliches (1990) expressed it, "In this desert of data, patent statistics loom up as a mirage of wonderful plenitude and objectivity" (p. 287). Even with potential defects, patenting records remain a good source for assessing technological change. As Griliches (1998) puts it, "Nothing else even comes close in the quantity of available data, accessibility, and the potential industrial, organizational, and technological detail," (p. 336).

Patent data is of a binomial nature; thus, the dependent variable will have a count nature (e.g., Baltagi, 2008; Greene, 2012). For these types of count data regressions, either a negative binomial or Poisson estimators should be applied (Hausman et al., 1984). A Poisson fixedeffects estimator will be used. There is some general criticism against the model choice that will be presented and a rebuttal.

The Poisson model has been criticized in the count panel data literature for its assumption that the variance is equal to its mean i.e., equi-dispersion. Thus, the Poisson distribution is often rejected in favor of models accommodating over-dispersion, i.e., where the variance is larger than the mean. The problem with the traditional Poisson distribution, which assumes equidispersion, is that the results contain incorrect standard errors of the parameter estimates. To

\footnotetext{
${ }^{9}$ There is criticism of the use of patent data as a proxy for technological development. Patents carry some properties that however make patent data a good proxy for innovation. Patents are to a large extent internationally standardized, (Rübbelke and Weiss, 2011). Moreover, it is hard to get a patent application approved: basically, several prerequisites are required where a patent must be: 'novel', 'useful', and 'non-obvious', and that has an inventive step (Griliches 1987; Hall and Ziedonis, 2001). Moreover, there are conceptual criticisms against the use of patent data as a measure of invention output. For example: all new inventions are patented, and patents differ greatly in their economic impacts (Pakes and Griliches, 1980, 378).
} 
model over-dispersion, therefore, the negative binominal specification is usually employed (e.g., Baltagi, 2008). The negative binominal specification modification relaxes the Poisson assumption (Greene, 2012). However, some have argued that the conditional fixed effects negative binomial estimator available in Stata (xtnbreg) should be avoided, since it is not a true fixed-effects estimator (see Allison and Waterman 2002; Greene 2007). A remedy is to use the Poisson fixed-effects estimator based on the Hausman, Hall and Griliches (1984) method (the count data equivalent to the within groups estimator), available in Stata as xtpoisson (contrary to what is commonly claimed, Poisson models estimated by pseudo-maximum likelihood as is the case in Stata are perfectly capable of dealing with both under and over-dispersion, as is explained by Santos Silva and Tenreyro, 2006). Hence, the negative binomial models offer no particular advantage. ${ }^{10}$

When one works with patent count models, there are frequently concerns about the presence of many zero (0) counts, especially when long time series are used (Blundell et al., 2002; Hu and Jefferson, 2009). A zero count means that an event did not occur, so many zero counts in terms of patents can be the result of countries that have not innovated at all, or which have tried but failed. This problem is partly remedied by the time period that is on the latter half of the development of solar power. The dependent variable is kept in its original form, rather than taking logs. This decision was made due to the presence of a significant portion of zeros: those values would be dropped if a logarithmic transformation were performed (Nicolli et al., 2012). The dependent variable will be a non-negative integer-valued variable with relatively few zeros, close to $9 \%$, and with small values at the beginning of the data set.

\section{Data Sources and Definitions}

\subsection{The Dependent Variable}

The dependent variable, granted patent applications, (priority year ${ }^{11}$ ) in solar energy is used. The patent data originates from the OECD Environment Directorate who collaborate with the Directorate for Science, Technology and Innovation. The OECD Environment Directorate have constructed patent-based innovation indicators to track developments in environment-related technologies. The patent statistics are constructed using data extracted from the Worldwide

\footnotetext{
${ }^{10}$ If a negative binomial model is used, an unconditional negative binomial estimator with both country and time dummies is far more preferable than the xtnbreg model.

${ }^{11}$ The priority date refers to the date when the patent was filed. Only patents filed under the Patent Cooperation Treaty (PCT) were included to approximate innovations in line with OECD recommendations (Hascic et al., 2009). The geographical location of the inventor is considered, and thus not the formal applicant since the applicant can be a company registered in a country other than where the knowledge was produced in the first place (e.g., Fischer et al., 2006).
} 
Patent Statistical Database (PATSTAT) of the European Patent Office (EPO) using algorithms developed by the OECD. ${ }^{12}$

The relevant patent documents were identified using search strategies for environment-related technologies (ENV-TECH). Which allow identifying technologies relevant to environmental management, water-related adaptation and climate change mitigation etc. Solar energy is one of the environmental energy categories. ${ }^{13}$

The patent count for solar energy patents are based OECD-data where a patent is granted at one patent jurisdiction in the world. The positive aspect of this selection approach is that it covers inventive activities on a broad scale. The negative is that the data will including many lowvalue inventions. ${ }^{14}$ The patents are based on the Inventor country - in cases of fractional counts by country of residence of the inventor(s); e.g. for a patent listing inventor from two different countries, each country will obtain a count of 0.5 , to avoid double-counting of inventions. Furthermore, the Priority date - the first filing date worldwide, under the Paris Convention is used as the patent date. The priority date is considered to be closest to the actual date of invention.

There is an understandable criticism apart from the usual pro-et-contra argument for patent data, as well as the choice of data source for a patent study, but for this particular study the data source is suitable. ${ }^{15}$ Alternative sources for selecting patent data have become available in addition to the Green Inventory Classification, that is a rather old classification and others have become available. ${ }^{16}$ E.g., IPC and EPO Y02E10/70 Cooperative Patent Classification class or the OECD ENVTECH Indicator. What motivates the use of the Green Inventory Classification (GIC) was to enable a study of inter-industry spillovers.

\subsection{The Independent Variables}

Following economic theory, the invention capabilities of a country are considered to depend fundamentally on three factors: (a) its invention infrastructure such as R\&D employees or R\&D expenditures as well as the stock of previous innovations (e.g. Romer, 1990; Grossman and Helpman, 1991); (b) its technological and economic specialization (Archibugi and Coco, 2005),

\footnotetext{
${ }^{12}$ Consistent with other patent statistics provided in OECD.Stat, only published applications for "patents of invention" are considered (i.e. excluding utility models, petty patents, etc.).

${ }^{13}$ An obvious argument against the use of this data is that some solar patents will not be counted. However, as a broad indicator of the existence of the phenomena we investigate the variable work, but any interpretation of the scale of the effect is not done. ${ }^{14}$ If data were to have been selected from cases where the patent would have been granted in more jurisdictions the data would have captured more high-quality inventions.

${ }^{15}$ See section 3.2 .

${ }^{16}$ See e.g., OECD, (2015) for an in-depth general discussion or Costantini et al, (2015b) for a discussion about pros and cons of the different data selection systems and a keyword-based methodology for patent analysis which was applied to the biofuels
} 
and (c) the quality of the linkages between its common infrastructure and those industries (Jungmittag, 2006). The aspects (a) to (c) are incorporated in the model with a number of control variables.

The spillovers measuring approach in this paper studies how a knowledge stock in one country affects inventive output in other countries. This stems from various previous studies (e.g., Klaassen et al., 2005; Mancusi, 2008; Aldieri and Cincera, 2009; Corradini et al., 2014). Firstly, the variable count of granted solar energy patents $\left(K_{n t}\right)$ is created to assess if there are domestic knowledge spillovers. The sources of spillovers - one of the questions of this study - were obtained by constructing two different Knowledge stocks, i.e., one national $\left(K_{n t}\right)$ the solar power sector ad one international knowledge stock $\left(I K_{n t}\right) .{ }^{17}$ One public solar power $R \& D$ stock $\left(R \& D S_{n t}\right)$ was created to investigate if an accumulation of $\mathrm{R} \& \mathrm{D}$ spending affected national output. ${ }^{18}$ The patent-based knowledge stock was constructed using the so-called perpetual inventory method commonly employed for related purposes (e.g., Ek and Söderholm, 2010). Specifically, this knowledge stock is constructed as follows:

$$
K_{n t}=(1-\delta) K_{n(t-1)}+R_{n(t-x)}
$$

where $K_{n t}$ is the knowledge stock in country $n$ during time period $t$. Moreover, $\delta$ is the annual depreciation rate of the knowledge stock $(0 \leq \delta \leq 1), P C_{n t}$ represents the count of patents, and $x$ is the number of years (lag) it takes before new patents add to the knowledge stock (Hall and Scobie, 2006). The time lag is assumed to be three years. Following the approach adopted in other studies (e.g., Griliches 1998; Corradini et al., 2014), a depreciation rate of $15 \%$ was applied to the knowledge stocks. ${ }^{19}$

Each country's initial national knowledge stock $\left(K_{0}\right)$ followed Grafström (2018a) suggestion and was calculated as:

$$
K_{0}=\frac{R_{0}}{g+\delta}
$$

where $R_{0}$ is the number of solar power patent counts in the first year in the dataset (1990), and $g$ is the average geometric growth rate of granted solar power patents and R\&D for the first ten years in the respective country. The motivation for calculating an initial stock is that we in some

\footnotetext{
${ }^{17}$ The international solar power knowledge stock available for country $\mathrm{n}$ is based on the accumulated granted solar power patent counts for all countries in the sample minus country n's own patents.

${ }^{18}$ Furthermore, in many patent count models the knowledge stock of previously filed patents is included to account for a country's absorptive capacity (Peters et al., 2012; Cohen and Levinthal, 1990).

${ }^{19}$ Park and Park (2006) calculated the technological knowledge stock depreciation rate for 23 different industries and found that it was in the realm of $11.9-17.9 \%$.
} 
cases can assume that there was solar power patent activity in the country prior to the starting year which therefore accounts for that activity. ${ }^{20}$

The $R \& D$ and $R \& D S$ variable respectively represents a flow and stock variable of government expenditure on solar energy R\&D in million USD (2014 prices). General- and specific purpose $\mathrm{R} \& \mathrm{D}$ is commonly considered when analyzing a country's inventive capacity (e.g. Romer, 1990; Grossman and Helpman, 1991; Dechezleprêtre et al., 2013; Furman et al., 2002). The data is derived from the International Energy Agency. This IEA data is known as possibly the best accessible data source of public R\&D expenditures in the energy sector (Garrone and Grilli, 2010).

Despite the fact that the IEA being a good data source, there are of course issues to consider (Bointner, 2014). For example, the database could be an incomplete representation of public support provided to energy R\&D (e.g., Arundel and Kemp, 2009). There are some consistency issues to consider with respect to the geographical coverage. For instance, Germany was reunified in 1991 but reports some missing data for the new Bundesländer (i.e., states formerly part of the German Democratic Republic) prior to 1992. Also, the R\&D data from regional governments are not provided by all countries (IEA, 2012). R\&D data from the private sector would have been both important and interesting to include, but a comprehensive form of such data was not available.

Public R\&D support is not the only channel for public support for individual firms; there are tax incentives, direct government funding, co-operation arrangements between firms, research institutes and universities, and loan guarantees. Hence, we use the Environmental Policy Stringency Index (ER) which is a relatively new index provided by the OECD that combines quantitative and qualitative information related to environmental policy (laws and regulations). The index's construction enables comparisons across countries, an issue that has been problematic before (Botta and Koźlak, 2014).

The Environmental Policy Stringency Index consists of environmental indicators corresponding to several policy instruments. The index covers the degree of stringency of 15 environmental policies, primarily related to climate and air pollution. ${ }^{21}$ The stringency ranges from 0 (not

\footnotetext{
${ }^{20}$ For some countries, the application of the average geometric growth rate did not matter as they had minimal $(0)$ patent activity observed in the initial years.

${ }^{21}$ Using an index gives some advantages over using single policies in the way that several studies, that examine the impact of demand-pull policies on the deployment of renewable energy, have done before; by using dummy variables that represent the existence of a support instrument. By paying somewhat more attention to the general effect of how instruments are designed, a somewhat better understanding of the policy effect should be reached (Baudry and Bonnet, 2018).
} 
stringent) to 6 (highest degree of stringency). The index is divided into two main subsets. There is a Market-based subset of instruments, with e.g., taxes on emissions, trading schemes (e.g., the European carbon allowances and the green certificates), systems of deposit and refund and FITs (feed in tariffs). The Non-market subset includes for example the norms concerning emissions ceilings and the limit of sulphur content in diesel, and governmental subsidies for renewable energy. ${ }^{22}$

Table 3 provides definitions and descriptive statistics for the variables that are used in the empirical investigation.

Table 3: Data definitions and descriptives

\begin{tabular}{|c|c|c|c|c|c|}
\hline Variable & Description & Mean & $\begin{array}{l}\text { Standard } \\
\text { deviation }\end{array}$ & Minimum & Maximum \\
\hline Patents granted & $\begin{array}{l}\text { Number (counts) of solar patents } \\
\text { over the time period } 1990-2014 \text {. }\end{array}$ & 98 & 297 & 0 & 2481 \\
\hline$R \& D$ & $\begin{array}{l}\text { Public expenditures on solar power } \\
\text { R\&D in million USD ( } 2014 \text { prices } \\
\text { and assuming purchasing power } \\
\text { parity). }\end{array}$ & 22.16 & 44.0 & 0 & 430 \\
\hline$R \& D$ stock & $\begin{array}{l}\text { Stock of public expenditures on solar } \\
\text { power R\&D in million USD ( } 2014 \\
\text { prices and assuming purchasing } \\
\text { power parity). }\end{array}$ & 100.98 & 200.55 & 0 & 1530 \\
\hline $\begin{array}{l}\text { National solar } \\
\text { stock }\end{array}$ & $\begin{array}{l}\text { Knowledge stock based on patents } \\
\text { granted to domestic inventors in the } \\
\text { field of solar power technology. }\end{array}$ & 385 & 1159 & 0 & 8997 \\
\hline $\begin{array}{l}\text { International } \\
\text { stock }\end{array}$ & $\begin{array}{l}\text { International solar power knowledge } \\
\text { stock. }\end{array}$ & 8776 & 9891 & 353 & 30193 \\
\hline $\begin{array}{l}\text { Environmental } \\
\text { Policy } \\
\text { Stringency Index } \\
(\text { ER) }\end{array}$ & $\begin{array}{l}\text { The stringency ranges from } 0 \text { (not } \\
\text { stringent) to } 6 \text { (highest degree of } \\
\text { stringency). }\end{array}$ & 1.78 & 0.94 & 0.20 & 4.13 \\
\hline
\end{tabular}

\section{Results}

Table 4 presents the empirical results from model specifications I-IV, i.e., the models addressing the presence of domestic knowledge spillovers in the solar power sector. Models I to IV covers the period 1990 - 2014 and models V - VIII cover the (later) period 2000 - 2014. The main coefficients of interest in Table 4 are those relating to the national solar stock and the International stock, respectively. Further tests will be displayed in table 5 (models V - VIII).

\footnotetext{
${ }^{22}$ In some, but not all countries there was a lack of reporting of the last two years, in those cases we have assumed that the policy stringency was equal to the previous year, this might possibly reduce the effect of the stringency variable since the trend has been more on the side of an increased stringency.
} 
Models I - II indicate that the variable National Stock is statistically significant and positive. Models III and IV show that the coefficient representing the international knowledge spillovers, International stock, was negative and statistically significant. The variable $R \& D$ flow has a contradictory, statistically significant coefficient in models I and III. In models II and IV, R\&D Stock showed statistically significant and positive results. R\&D data from the private sector would have been both important and interesting to include, but a comprehensive form of such data was not available and was hence not included. The policy stringency variable was statistically significant and positive in all models.

Table 4: Parameter estimates for models I-IV, time period 1990-2014.

\begin{tabular}{|c|c|c|c|c|}
\hline Variable & Model V & Model VI & Model VII & Model VIII \\
\hline National Stock & $\begin{array}{c}0.677 * * * \\
(51.85)\end{array}$ & $\begin{array}{c}0.508 * * * \\
(33.32)\end{array}$ & & \\
\hline International Stock & & & $\begin{array}{c}-0.634 * * * \\
(-28.03)\end{array}$ & $\begin{array}{c}-0.425 * * * \\
(-14.85)\end{array}$ \\
\hline$R \& D$ flow & $\begin{array}{c}-0.040 * * * \\
(-7.17)\end{array}$ & & $\begin{array}{c}0.075^{* * *} \\
(14.53)\end{array}$ & \\
\hline$R \& D$ Stock & & $\begin{array}{c}0.209 * * * \\
(12.37)\end{array}$ & & $\begin{array}{c}0.522 * * * \\
(39.27)\end{array}$ \\
\hline Policy Stringency & $\begin{array}{c}0.195 * * * \\
(19.40) \\
\end{array}$ & $\begin{array}{c}0.225 * * * \\
(21.88) \\
\end{array}$ & $\begin{array}{c}0.143^{* * * *} \\
(14.83) \\
\end{array}$ & $\begin{array}{c}0.228 * * * \\
(22.67) \\
\end{array}$ \\
\hline Wald chi2 & 39147 & 39116 & 40241 & 40007 \\
\hline Observations & 616 & 616 & 616 & 616 \\
\hline Log-likelihood & -3862 & -3812 & -5014 & -4306 \\
\hline Prob $>=$ chibar 2 & 0.000 & 0.000 & 0.000 & 0.000 \\
\hline Time fixed effects & Yes & Yes & Yes & Yes \\
\hline Country Fixed effects & Yes & Yes & Yes & Yes \\
\hline
\end{tabular}

Table 5 displays the results from models V-VIII, i.e., addressing the later time period (2000 2014). Models V - VII indicate that the variable National Stock is statistically significant and positive. Models VI and VIII show that the coefficient representing the international knowledge spillovers, International stock, was negative and statistically significant. The variable $R \& D$ flow has statistically significant coefficient negative results in models VI and VIII. In models VI and VIII, $R \& D$ Stock showed statistically significant and positive results. The policy stringency variable was statistically significant and positive in all models.

Table 5: Parameter estimates for models VI-X, time period 2000-2014

\begin{tabular}{lcccc}
\hline \hline Variable & Model V & Model VI & Model VII & Model VIII \\
\hline \hline National Stock & $0.519 * * *$ & $0.270 * * *$ & & \\
& $(29.76)$ & $(13.02)$ & & $-1.479 * * *$ \\
International Stock & & & $(-20.84)$ & $-0.311 * * *$ \\
& & & $-0.0362 * * *$ &
\end{tabular}




\begin{tabular}{lcccc} 
& $(-8.00)$ & & $(-5.93)$ & $0.431 * * *$ \\
R\&D Stock & & $0.306^{* * *}$ & & $(22.18)$ \\
Policy Stringency & $0.09 * * *$ & $0.149 * * *$ & $0.028 * *$ & $0.125 * * *$ \\
& $(7.67)$ & $(11.86)$ & $(2.43)$ & $(10.01)$ \\
\hline \hline Wald chi2 & 13782 & 13795 & 13590 & 13828 \\
Observations & 336 & 336 & 336 & 336 \\
Log-likelihood & -2606 & -2529 & -2836 & -2606 \\
Prob>=chibar2 & 0.000 & 0.000 & 0.000 & 0.000 \\
Time fixed effects & Yes & Yes & Yes & Yes \\
Country Fixed effects & Yes & Yes & Yes & Yes \\
\hline \hline
\end{tabular}

Notes: $* * *$ and $* * *$ indicate statistical significance at the $10 \%, 5 \%$ and $1 \%$ levels, respectively.

\section{Discussion}

\subsection{National and international knowledge spillovers}

The variable national solar stock had a statistically significant positive coefficient in models I, II, V and VI. The statistically significant and positive result suggests that previous solar power research output in a country can affect the domestic capacity for realizing future inventions in a positive way. In other words, the inventive capacity in the solar field was improved by knowledge accumulation in the solar power field. The findings also show that the domestic accumulation of patents is important for the potential development of new ones (much in line with e.g., Antonelli, 2008; Antonelli and Quatraro, 2010; Costantini and Crespi, 2008a, 2008b; Dosi et al., 1988; Fagerberg et al., 2005; Rennings, 2000). Thus, domestic patents add to a national knowledge stock, in turn suggesting that early investment in a specific technology can be an indicator of future leadership in that field. These results were rather expected and followed results in similar studies on other technologies (see e.g., Klaassen et al., 2005; Mancusi, 2008; Aldieri and Cincera, 2009; Braun 2011; Corradini et al., 2014; Lehmann, 2013; Grafström 2018a, c; Grafström and Lindman 2017).

The overall findings of this analysis reveal interesting results regarding the state of international knowledge spillovers in the solar sector. The results indicate that a large build up in neighboring countries' patents stock in the solar sector have a negative effect on the buildup of an own knowledge stock. Hence, there might be incentives for free-riding (as suggested by e.g., Mansfield et al., 1977; Jaffe et al., 2005; Popp, 2005; Fischer, 2008) because countries might try to absorb spillovers and make use of the technologies invented abroad.

For a laggard country, the free-riding approach might not be a problem if the value of turbine sales and patent-use revenues are high enough. If, however, it can be shown that incentives exist that encourage free-riding - and that such free-riding has a negative effect on the goal 
fulfillment regarding renewable energy generation in the EU - then public policies should seek to discourage such behavior because it could affect the speed at which low-cost renewable energy production diffuses in western Europe.

\subsection{R\&D and Policy Stringency}

The results in this paper highlight that long running public R\&D spending policies and policy stringency plays an important role in stimulating innovation in the solar energy sector. The year to year R\&D spending was however statistically significant and negative. The policy stringency variable was statistically significant and positive in all estimations - indicating that the more emphasis a state puts on environmental efforts (fiscal and legal) the higher output of solar patents the country has.

Public R\&D funding are said to be needed since private firms have too weak incentives to make R\&D investments in clean energy technologies (Jaffe et al., 2005; Edenhofer et al., 2013). Another argument for why public policies need to combine the standard environmental policies (such as carbon taxes or permits) with $R \& D$ support in clean technologies is that once the knowledge base in clean energy is large enough, firms will start innovating; rendering public policy intervention only temporary (Acemoglu et al., 2012, Aalbers et al., 2013). Hence, improved information on what kind of policies benefit existing technologies and what kind of policies have the potential to increase technological variety has important implications for policy makers who want to engage in R\&D spending.

The analysis developed here shows that year to year (flow) public R\&D funding appeared to have a small negative effect. One possible explanation is that technological change is a long run process where it takes a long accumulation period of knowledge before inventions can be made. A decreased return to innovation spending might also have been revealed. Alternatively, a late spending increase might indicate that countries that are laggard are trying to catch up but with initial low level of invention output. These findings therefore matter for public science strategies, technology and innovation policies.

\section{Concluding Remarks and Directions for Future Research}

The purpose of this paper is to provide an updated analysis of international knowledge spillovers in the solar energy sector. Specifically, the paper investigates how the accumulation of solar energy patents and public R\&D spending affected the output of domestic granted solar energy patents. The econometric analysis relies on a data set consisting of most of the OECD countries plus China and analyzes two time periods; from 1990 to 2014 and the years 2000 to 
2014. To analyze the data material, a Poisson fixed-effects estimator based on the Hausman, Hall and Griliches (1984) method was used since the model allows for count data.

The empirical findings suggest that the domestic accumulation of patents and R\&D is important for the potential development of new ones. Indeed, early investment in specific technology can be an indicator of future leadership in that field. It also seems to be the case that long running investments work better for a country that wants to be a part of the development of a particular technology.

There are several ways to improve the analysis carried out here if newer data could be obtained and soon enough time will have elapsed, to allow for a comprehensive analysis of the development in the last two decades, which has been highly important for the development of solar power. An obvious way to do this is by having observations of the same country across a greater number of periods, including before, during and after various major changes in technology. This should allow a better control for unobserved country specific effects. The analysis presented here is just a step for a better understanding of the effects of public R\&D subsidies and the effect of investments in a specific technology. The paper is focused around the knowledge production function, but further research could be extended to factors that affect diffusion more and study its contribution to knowledge spillovers.

Outstanding questions include: does government-sponsored energy technology research outcompete private initiatives? Are there ways of improving R\&D resource allocations? Additional analyses should devote more attention to related themes in order to broaden the understanding of environmental technological change. Such themes include the determinants of the development and diffusion of different types of renewable energy technologies; many types of technologies face their own challenges. Naturally, since this thesis only attempts to provide answers to questions concerning a limited part of the entire technological development process, the field for future research should be wide. If we want to predict and understand how the new renewable energy technologies develop over time and what policy makers can do to stimulate this development, it is essential to continue to improve our understanding of the subject. 


\section{References}

Aalbers, R., V. Shestalova, and V. Kocsis. 2013. "Innovation Policy for Directing Technical Change in the Power Sector.” Energy Policy, 63, 1240-1250.

Acemoglu, D., P. Aghion, L. Bursztyn, and D. Hemous. 2012. "The Environment and Directed Technical Change." American Economic Review, 102(1), 131-166.

Adams, S. S. 2005. Information Sources in Patents. 1st ed. Munich: K. G. Saur Verlag.

Aldieri, L., and M. Cincera. 2009. "Geographic and Technological R\&D Spillovers within the Triad: Micro Evidence from US Patents.” The Journal of Technology Transfer, Vol. 34 (2): 196-211.

Allison P. D. and R. P. Waterman, 2002. "Fixed-Effects Negative Binomial Regression Models." Sociological Methodology 32:247- 265.

Antonelli, C. (2008). Localised technological change: Towards the economics of complexity. London: Routledge.

Antonelli, C., and Quatraro, F. (2010). The effects of biased technological change on total factor productivity: Empirical evidence from a sample of OECD countries. Journal of Technological Transfer, 35(4):361-383.

Arellano, M., and O. Bover (1995). "Another Look at the Instrumental-Variable Estimation of ErrorComponents Models", Journal of Econometrics, 68 (1): 29-52.

Arrow, K. J. 1962. "The Economic Implications of Learning by Doing." The Review of Economic Studies, Vol. 29 (3): 155-173.

Baltagi, B. H. (2008). Econometric Analysis of Panel Data. 4th ed. Hoboken, NJ: John Wiley \& Sons.

Baudry, M. and Bonnet, C. (2018 in press) "Demand-Pull Instruments and the Development of Wind Power in Europe: A Counterfactual Analysis", Environmental Resource Economics.

Blundell, R. and S. Bond. (1998). "Initial Conditions and Moment Restrictions in Dynamic Panel Data Models", Journal of Econometrics, Vol. 87 (1): 115-43.

Botta, E., and Kozluk, T. (2014). "Measuring environmental policy stringency in OECD countries: A composite index approach". OECD Economic Department Working Papers, (1177), 0_1.

Braun, F.G., J. Schmidt-Ehmcke, P., Zloczysti. 2011. "Innovative Activity in Wind and Solar Technology: Empirical Evidence on Knowledge Spillovers Using Patent Data." Discussion paper 993, German Institute for Economic Research, Germany.

Budd, A., and Hobbis, S. (1989a). Co-integration, technology and the long-run production function. Discussion paper, Centre for Economic Forecasting, London Business School, July 1989.

Budd, A., and Hobbis, S. (1989b). Output growth and measure of technology. Discussion paper, Centre for Economic Forecasting, London Business School, July 1989.

Cohen, W. M., and Levinthal, D. A. 1989. "Innovation and Learning: the two Faces of R\&D." The Economic Journal, Vol. 99 (397): 569-596.

Cohen, W. M., and D. A. Levinthal. 1990. "Absorptive Capacity: A New Perspective on Learning and Innovation.” Administrative Science Quarterly, Vol. 35: 128-152.

Cohen, W. M., R. R. Nelson, and J. P. Walsh. 2000. "Protecting their Intellectual Assets: Appropriability Conditions and Why US Manufacturing Firms Patent (or Not)." National Bureau of Economic Research Working Paper Series No. 7552. Cambridge, MA: NBER.

Costantini, V., and Crespi, F. (2008a). Environmental regulation and the export dynamics of energy technologies. Ecological Economics, 66(2):447-460.

Costantini, V., and Crespi, F. (2008b). Environmental institutions and the trade of energy technologies in Europe. International Journal of Global Environmental Issues, Vol. 8(4):445-460. 
Costantini, V., Crespi F., Martini, C., and L., Pennacchio. (2015a). "Demand-Pull and Technology-Push Public Support for Eco-Innovation: The Case of the Biofuels Sector", Research Policy, Vol. (44): 577-595.

Corradini, M., V. Costantini, S. Mancinelli, and M. Mazzanti. 2015. "Interacting Innovation Investments and Environmental Performances: A Dynamic Impure Public Good Model." Environmental Economics and Policy Studies, Vol. 17 (1): 109-129.

Corradini, M., V. Costantini, S. Mancinelli, and M. Mazzanti. 2014. "Unveiling the Dynamic Relation between R\&D and Emission Abatement: National and Sectoral Innovation Perspectives from the EU." Ecological Economics, Vol. 102: 48-59.

De Vries, F. P., and C. Withagen. 2005. "Innovation and Environmental Stringency: The Case of Sulfur Dioxide Abatement.” Center Discussion Paper Series No. 2005-18, Tilburg University, Tilburg.

Dechezleprêtre, A., R. Martin, and M. Mohnen. 2013. "Knowledge Spillovers from Clean and Dirty Technologies: A Patent Citation Analysis." Centre for Climate Change Economics and Policy Working Paper No. 151 and Grantham Research Institute on Climate Change and the Environment Working Paper No. 135. Leeds/London: University of Leeds/London School of Economics.

Dekker, T., H. Vollebergh, F. de Vries, and C. Withagen. 2012. "Inciting Protocols." Journal of Environmental Economics and Management, 64, 45-67.

Dietz, S., and D. S. Maddison (2009). "New Frontiers in the Economics of Climate Change", Environmental Research Economics, Vol. (43): 295-306.

Dosi, G., Freeman, C., Nelson, R., Silverberg, G., and Soete, L. (1988). Technical change and economic theory. London: Pinter.

Edenhofer, O., Hirth, L., Knopf, B., Pahle, M., Schlömer, S., Schmid, E., \& Ueckerdt, F. (2013). On the economics of renewable energy sources. Energy Economics, 40, S12-S23.

Ek, K., and P. Söderholm. 2010. "Technology Learning in the Presence of Public R\&D: The Case of European Wind Power." Ecological Economics, Vol. 69 (12): 2356-2362.

Engelbrecht, H.J., 2002. Human capital and international knowledge spillovers in TFP growth of a sample of developing countries: an exploration of alternative approaches. Applied Economics 34, 831-841.

Fagerberg, J., Mowery, D., and Nelson, R. (eds). (2005). The Oxford Handbook of Innovation. Oxford: Oxford University Press.

Fagerberg, J., 1988. “International Competitiveness.” Economic Journal 98 (391), 355-374.

Fischer, C. 2008. "Emissions pricing, spillovers, and public investment in Environmentally Friendly Technologies." Energy Economics, Vol. 30 (2): 487-502.

Fischer, M. M., T. Scherngell, and E. Jansenberger. 2006. "The Geography of Knowledge Spillovers between High-technology Firms in Europe: Evidence from a Spatial Interaction Modeling Perspective." Geographical Analysis, Vol. 38 (3): 288-309.

Garrone, P., and L. Grilli. 2010. "Is There a Relationship Between Public Expenditures in Energy R\&D and Carbon Emissions Per GDP? An Empirical Investigation.” Energy Policy, 38 (10): 56005613.

Glaeser, E., Kallal, H., Scheinkman, J., Shleifer, A., 1992. "Growth in Cities." Journal of Political Economy 100, 1127-1152.

Grafström, J., and Å. Lindman. 2017. "Invention, Innovation and Diffusion in the European Wind Power Sector." Technological Forecasting and Social Change, 114: 179-191.

Grafström, J. (2018a). "International Knowledge Spillovers in the Wind Power Industry: Evidence from the European Union." Economics of Innovation and New Technology, 1-20. 
Grafström, J. (2018b). Divergence of renewable energy invention efforts in Europe: an econometric analysis based on patent counts. Environmental Economics and Policy Studies, 1-31.

Greene, W. H. (2007). "Fixed and Random Effects Models for Count Data", Leonard N. Stern School of Business Paper No. ISSN 1547-3651. New York, NY: New York University Stern School of Business.

Greene, W. H. 2012. Econometric Analysis. 7th ed. Essex: Pearson Education.

Griliches, Z. 1979. "Issues in Assessing the Contribution of Research and Development to Productivity Growth." The Bell Journal of Economics, Vol. 10 (1): 92-116.

Griliches, Z. 1987. "R\&D and Productivity: Measurement Issues and Econometric Results." Science, Vol. 237 (4810): 31-35.

Griliches, Z. 1992. “The Search for R\&D Spillovers.” Scandinavian Journal of Economics, Vol. 28: 1661-1707.

Griliches, Z. (1990). Patent statistics as economic indicators: A survey. Journal of Economic Literature, 28(4):1661-1707.

Griliches, Z. (1998). Patent statistics as economic indicators: A survey. Eds. Zvi Griliches $R \& D$ and productivity: The econometric evidence. Chicago: University of Chicago Press, 287-343.

Hall, B. H., and R. H. Ziedonis. 2001. "The Patent Paradox Revisited: An Empirical Study of Patenting in the US Semiconductor Industry, 1979-1995." The RAND Journal of Economics, Vol. 32 (1): $101-128$.

Hall, J., and G. Scobie. 2006. "The Role of R\&D in Productivity Growth: The Case of Agriculture in New Zealand: 1927 to 2001." Wellington: New Zealand Treasury

Hausman, J., B. H. Hall, and Z. Griliches. 1984. "Econometric Models for Count Data with an Application to the Patents-R\&D Relationship." Econometrica, Vol. 52 (4): 909-938.

Hu, A. G., and G. H. Jefferson. (2009). "A Great Wall of Patents: What is Behind China's Recent Patent Explosion?”, Journal of Development Economics, Vol. 90 (1): 57-68.

Hussler, C. 2004. "Culture and Knowledge Spillovers in Europe: New Perspectives for Innovation and Convergence Policies?" Economics of Innovation and New Technology, Vol. 13 (6): 523-541.

Ibenholt, K. 2002. "Explaining Learning Curves for Wind Power.” Energy Policy, Vol. 30 (13): 11811189.

Intergovernmental Panel on Climate Change (IPCC) (2007). Climate Change 2007: The Physical Science Basis, Contribution of Working Group I to the Fourth Assessment, Report of the Intergovernmental Panel on Climate Change, Geneva.

Intergovernmental Panel on Climate Change (IPCC) (2013). Climate Change 2013: The Physical Science Basis, Contribution of Working Group I to the Fifth Assessment, Report of the Intergovernmental Panel on Climate Change, Geneva.

Jaffe, A.B., Stavins, R.N., 1995. Dynamic incentives of environmental regulations: the effects of alternative policy instruments on technology diffusion. J. Environ. Econ. Manag. 29 (3), S43S63.

Jaffe, A. B., R. G. Newell, and R. N. Stavins. 2005. "A Tale of Two Market Failures: Technology and Environmental Policy.” Ecological Economics, Vol. 54 (2): 164-174.

Jungmittag, A. (2004). Innovations, technological specialization and economic growth in the EU. International Economics and Economic Policy, 1(2-3):247-273.

Jungmittag, A., and Welfens, P. J. J. (2002). Telecommunications, innovations and the long-term production function: Theoretical aspects and a cointegration analysis for West Germany 1960 1990. In Audretsch, D., and Welfens, P. J. J. (eds.), The New Economy and economic growth in Europe and the US. Springer-Verlag Berlin Heidelberg, 99-127. 
Jungmittag, A., Blind, K., and Grupp, H. (1999). Innovation, standardisation and the long-term production function - A cointegration analysis for Germany, 1960-1996. Zeitschrift für Wirtschafts- und Sozialwissenschaften, 119:205-222.

Joutz, F. L., and M. Y. Abdih. 2005. "Relating the Knowledge Production Function to Total Factor Productivity: An Endogenous Growth Puzzle" Working paper (No. 5-74). International Monetary Fund (IMF). Middle East and Central Asia Department.

Johnstone, N., Managi, S., Rodríguez, M. C., Haščič, I., Fujii, H., \& Souchier, M. (2017). Environmental policy design, innovation and efficiency gains in electricity generation. Energy Economics, 63, 106-115.

Johnstone, N., I. Hascic, and D. Popp. (2010). "Renewable Energy Policies and Technological Innovation: Evidence Based on Patent Counts", Environmental and Resource Economics, Vol. 45 (1): 133-155.

Johnstone, N., Haščič, I., Poirier, J., Hemar, M., \& Michel, C. (2012). Environmental policy stringency and technological innovation: evidence from survey data and patent counts. Applied Economics, 44(17), 2157-2170.

Klaassen, G., A. Miketa, K. Larsen, and T. Sundqvist. 2005. "The Impact of R\&D on Innovation for Wind Energy in Denmark, Germany and the United Kingdom." Ecological Economics, Vol. 54 (2-3): 227-240.

Krammer, S. 2009. "Drivers of National Innovation in Transition: Evidence from a Panel of Eastern European Countries.” Research Policy, Vol. 38 (5): 845-860.

Lehmann, P., and Gawel, E. (2013). Why should support schemes for renewable electricity complement the EU emissions trading scheme?. Energy Policy, 52, 597-607.

Mancusi, M. L. 2008. "International Spillovers and Absorptive Capacity: A Cross-country Cross-sector Analysis Based on Patents and Citations." Journal of International Economics, Vol. 76 (2): 155165.

Mansfield, E. 1977. The Production and Application of New Industrial Technology. Norton.

Nelson, R., Phelps, E., 1966. Investment in humans, technological diffusion, and economic growth. American Economic Review: Papers and Proceedings 51 (2), 69-75.

Nicolli, F., N. Johnstone, and P. Söderholm. 2012. "Resolving Failures in Recycling Markets: The Role of Technological Innovation.” Environmental Economics and Policy Studies, 14 (3): 261-288.

Pakes, A. 1985. “On Patents, R\&D, and the Stock Market Rate of Return.” Journal of Political Economy 93 (2): 390-409.

Pakes, A., and Z. Griliches. 1980. "Patents and R\&D at the Firm Level: A First Report." Economics Letters 5 (4): 377-381.

Peters, M., Schneider, M., Griesshaber, T., and Hoffmann, V. H. 2012. "The Impact of TechnologyPush and Demand-Pull Policies on Technical Change - Does the Locus of Policies Matter?" Research Policy, Vol. 41 (8): 1296-1308.

Popp, D. 2002. "Induced Innovation and Energy Prices." American Economic Review, 92, 160-180.

Popp, D. 2005. "Lessons from Patents: Using Patents to Measure Technological Change in Environmental Models." Ecological Economics, Vol. 54 (2): 209-226.

Poirier, P., N. Johnstone, I. Haščič, and J. Silva. 2015. "The Benefits of International Co-Authorship in Scientific Papers: The case of wind energy Technologies." OECD Environment Working Papers 81, OECD Publishing.

Schankerman, M., and A. Pakes. 1987. "Estimates of the Value of Patent Rights in European Countries During the Post-1950 Period.” National Bureau of Economic Research Working Paper No. 1650 (Also Reprint No. r0861). Cambridge, MA: NBER 
Scherer, F. M., and D. Harhoff. 2000. "Technology Policy for a World of Skew-Distributed Outcomes." Research Policy, 29 (4): 559-566.

Rennings, K. (2000). Redefining Innovation-Eco-Innovation Research and the Contribution from Ecological Economics. Ecological Economics, 32(2):319-332.

Rübbelke, D., and P. Weiss. (2011). "Environmental Regulations, Market Structure and Technological Progress in Renewable Energy Technology: A Panel Data Study on Wind Turbines", Fondazione Eni Enrico Mattei Working Paper Series. Milan: Fondazione Eni Enrico Mattei.

Santos Silva, J. M. C. and Tenreyro, S. (2006). "The Log of Gravity." The Review of Economics and Statistics, 88(4), 641-658. 7, 9, 21.

Suganthi, L., and A. Samuel (2012). "Energy Models for Demand Forecasting: A Review", Renewable and Sustainable Energy Reviews, Vol. 16 (2): 1223-1240.

Stern, N. (2007). The Economics of Climate Change: The Stern Review. Cambridge University Press, New York.

Söderholm, P., and G. Klaassen. 2007. "Wind Power in Europe: A Simultaneous Innovation-Diffusion Model." Environmental and Resource Economics, Vol. 36 (2): 163-190.

Tang, T. (2018). Explaining technological change in the US wind industry: Energy policies, technological learning, and collaboration. Energy Policy, 120, 197-212.

Trajtenberg, M. 2001. "Innovation in Israel 1968-1997: A Comparative Analysis Using Patent Data." Research Policy, 30 (3): 363-389.

Verspagen, B. (1991). A New Empirical Approach to Catching Up or Falling Behind. Structural Change and Economic Dynamics, 2(2), 359-380.

Appendix 1

Robustness 